\title{
Energy intakes, anthropometry and body composition of Nigerian adolescent girls: a case study of an institutionalized secondary school in Ibadan
}

\author{
BY ABIODUN H. COLE ${ }^{1}$, OMOWUMI O. TAIWO ${ }^{1}$, NGOZI I. NWAGBARA ${ }^{1}$ \\ AND CORNELIA E. COLE ${ }^{2}$ \\ ${ }^{1}$ Human Energy Metabolism Research Laboratory, Department of Human Nutrition, College of Medicine, \\ University of Ibadan, Ibadan, Nigeria \\ ${ }^{2}$ International School, University of Ibadan, Ibadan, Nigeria
}

(Received 24 September 1993 - Revised 29 August 1995 - Accepted 19 December 1995)

\begin{abstract}
Twenty-two apparently healthy Nigerian adolescent girls aged 11-17 years residing in a hostel, were studied over five consecutive days in order to assess their energy intake (EI), energy cost of specific activities and body composition (BC). The mean characteristies of the group were: height 1.58 (SD $0 \cdot 1$, range 1.42-1.68) $\mathrm{m}$, body weight $49 \cdot 1$ (SD 7.9, range 34.0-61.0) $\mathrm{kg}$ and BMI $19 \cdot 5$ (SD 2.0, range $16 \cdot(-23 \cdot 0) \mathrm{kg} / \mathrm{m}^{2}$. The food intake of each subject was assessed by direct weighing and its energy value was determined by means of a ballistic bomb calorimeter. BMR values were calculated according to Food and Agriculture Organization/World Health Organization/United Nations University (FAO/WHO/UNU) (1985) equations. Percentage body fat (BF \%) values were derived from three skinfold thickness measurements, using population-specific equations. The adolescents' mean daily EI was found to be 6510 (SD 855) $\mathrm{kJ} / \mathrm{d}(138 \cdot 3$ (SD 27.8) $\mathrm{kJ} / \mathrm{kg}$ body weight per d) which is lower than the FAO/WHO/UNU (1985) calculated energy requirement of $8800 \mathrm{~kJ} / \mathrm{d}$ for adolescent girls aged 12-14 years. The contributions of specific nutrients and individual meals to the total EI were: carbohydrate, protein and fat, $59.2,12.5$ and $28.3 \%$ of energy respectively and breakfast, lunch and supper, $21.5,41.0$ and $37.4 \%$ respectively. However, the mean BMR was $5627 \mathrm{~kJ} / \mathrm{d}$, which is comparable with that given by FAO/WHO/UNU (1985) for adolescent girls aged 13-14 years. The mean BF \% was found to be 21.7. The comparatively low EI of the participants in the present study may be indicative of energy deficiency in their meals. This assumption is also reflected in their BC values. Nevertheless, further studies of this kind on adolescents in Nigeria are needed to confirm these observations.
\end{abstract}

Energy intake: Anthropometry: Indirect calorimetry: Body composition: Adolescence

Energy and nutrient intakes are important health variables particularly during adolescence. This is because the adolescent years are periods of great physical and emotional change during which a child develops and enters adulthood. The physical changes occur over a relatively short period of time, usually about 2 years for Europeans and Americans, and 24 years in some cases for Africans (Barasi \& Mottram, 1992). There are substantial gains in height and body weight, these being greater for boys than for girls.

No previous studies of the energy intake (EI), energy cost of specific activities (ECSA), indirect calorimetry (IC), skinfold thickness (SFT) and body composition (BC) have been carried out on adolescents in Nigeria. Although information on adolescents' energy and nutrient intakes abounds in the literature for the United States, UK, Germany and Australia, there is a paucity of corresponding information for any country in Africa.

According to Food and Agriculture Organization/World Health Organization (FAO/WHO) (1973) estimates, energy requirements for adolescent girls aged 10-12, 
13-15 and 16-19 years are $9832 \mathrm{~kJ}(2350 \mathrm{kcal}) / \mathrm{d}, 10418 \mathrm{~kJ}(2490 \mathrm{kcal}) / \mathrm{d}$ and $9665 \mathrm{~kJ}$ $(2310 \mathrm{kcal}) / \mathrm{d}$ respectively. However, EI values published by the Food and Agriculture Organization/World Health Organization/United Nations University (FAO/WHO/UNU) (1985) for female adolescents aged 14-15 years are $8996 \mathrm{~kJ}(2150 \mathrm{kcal}) / \mathrm{d}$, which are slightly lower than the FAO/WHO (1973) values.

The present paper reports, for the first time, the results of IC, anthropometry and BC measurements made on a group of adolescent girls in Nigeria. The study is part of an extensive on-going prospective investigation. The present study was initiated primarily to obtain information on EI and the contributions of the different energy-yielding nutrients to the total EI intake of adolescent girls. The results are compared with the FAO/WHO (1973) and FAO/WHO/UNU (1985) recommended values. The percentage body fat (BF\%) was also assessed through SFT measurements, using population-specific equations derived from a survey of North-European adolescent girls as a basis for prospective computations.

\section{METHODS}

\section{Subjects}

Twenty-two apparently healthy institutionalized adolescent girls of the International School (ISI), University of Ibadan, Ibadan, Nigeria, aged between 11 and 17 years were the subjects of the study. They were selected at random (1 in 5) from the 110 boarders at ISI, who belong to families of different ethnic and socioeconomic groups and are considered to be typical of average Nigerian girls. Characteristics of the subjects are given in Table 1 .

The Ethical Committee of the College of Medicine, University of Ibadan, approved all the experimental procedures and protocols before the commencement of the study. Informed consent of the adolescent girls was sought and obtained before commencement of the experiments.

\section{Food intake (FI)}

The subjects ate their meals (breakfast, lunch and supper) in the school cafeteria on each of the five consecutive days of the study. Fresh green vegetables or fruits were not included in the menu. There was no evidence of consumption of fruits such as fresh bananas, pawpaw, apples, mangoes or oranges. Bulky staple foodstuffs such as yam flour (amala) and cassava starch (fufu) were also not served.

The consumption of snacks between meals was minimal and did not contribute significantly to EI.

In Nigeria, especially among the Yoruba speaking people of the South-West where the present study was conducted, the staple diet consists of items such as maize flour (eko tutu), cassava (Manihot esculenta) flour (gari) and yam (boiled or pounded). Such items were served to the girls in the present study. (For details of the dietary patterns of the Yoruba, see Cole \& Ogungbe, 1987.)

\section{Food intake measurements}

At meal times (07.00-07.30 hours (breakfast), 14.00-15.00 hours (lunch) and 18.00-18.30 hours (supper)), the investigators and two female field officers from our laboratory in Ibadan assembled in the cafeteria of the school to record FI. Salter dietary balances, 
calibrated up to $10 \mathrm{~kg}$ at intervals of $50 \mathrm{~g}$, were used for the measurements. Plate waste was weighed and deducted from the original weight of food. Hence, a representative sample of the diet was submitted to subsequent analysis. All the items of food making up the diet, such as meat and fish, were specially selected for uniformity. No visible fats on meats were observed in the diets to warrant trimming so as to avoid any variation from portion to portion, as reported by Southgate \& Durnin (1970). The total FI of each adolescent girl was measured for five consecutive days, including a weekend, by this weighed inventory method (Durnin et al. 1957; Garry et al. 1959; Marr, 1971).

Bread was given in half-loaves with butter spread thinly inside before being served. Snack-type foods consumed at lunch or supper times were also weighed and recorded. The resultant values were added to the values for the specified meal. Samples of all foods, including snacks, consumed by individual girls were collected in labelled plastic containers for chemical analysis. For snacks such as carbonated drinks, and for butter, sugar and milk, standard values for energy contents were obtained when necessary from food composition tables (Haenel, 1979).

\section{Chemical analysis of the sample}

The food samples were analysed for energy, fat and protein according to methods recommended by the Association of Official Analytical Chemists (AOAC) (1980). Carbohydrate was calculated by difference. Coefficients of variation (\%) for these analyses were: fat $5 \cdot 3$, protein $4 \cdot 0$, and carbohydrate $2 \cdot 4$.

The chemical analyses, except for moisture determination, were carried out on ovendried samples. The material was dried at $70-80^{\circ} \mathrm{C}$ for $20 \mathrm{~h}$ and then at $100-105^{\circ}$ for $24 \mathrm{~h}$ to a constant weight using a Gallenkamp moisture extraction oven, model OV 440 (Gallenkamp and Co., London).

Accurately weighed food samples were exhaustively extracted by refluxing for $5 \mathrm{~h}$ with petroleum ether in a Soxhlet apparatus. After removing the solvent in a rotary evaporator, the weight of the extracted fat was determined as a percentage of the original sample.

N content was analysed by the semi-micro Kjeldahl procedure (AOAC, 1980). Digestion of the sample was carried out on a Techne Dri-block DB4 system, with subsequent distillation by means of the Markam apparatus. The distillate was titrated against $0.01 \mathrm{M}-\mathrm{HCl}$ and the percentage of $\mathrm{N}$ was calculated thereafter. The protein value was derived from the $\mathrm{N}$ content by multiplying by a factor of 6.25 .

For ash determination, $5 \mathrm{~g}$ finely ground dry sample was weighed into a porcelain crucible. The sample was charred over a Bunsen flame and then transferred into a preheated Gallenkamp muffle furnace (size 2, no. FR614, Gallenkamp and Co. Ltd) at $600^{\circ}$ for $2 \mathrm{~h}$. The crucible was transferred to a desiccator to cool before weighing.

The energy values of the samples were determined using a ballistic bomb calorimeter (CB-370, Gallenkamp) with benzoic acid as standard (AOAC, 1980).

\section{Anthropometry}

The ages of the girls were supplied by individual subjects and confirmed from school records. Height (m) measurements, without shoes, were determined with vertical measuring rods comprising fixed metal scales, designed by Cole (unpublished results). Body weight (kg), without shoes and in light clothing, was measured using a Portable Floor Salter Scale Model 109 (Salter Industrial Measurements Limited, Shropshire). 


\section{Skinfold thickness}

SFT was measured to the nearest $\mathrm{mm}$, except for low values (usually $5 \mathrm{~mm}$ or less) when it was taken to the nearest $0.5 \mathrm{~mm}$. These readings were made at three sites, triceps, subscapular and suprailiac, on all adolescent girls, using "Somet" calipers manufactured in Czechoslovakia. These three SFT values were used to estimate BF\% of the subjects. The measurements, made by two investigators, were usually done on the right side of the body with the girls standing in a relaxed position. Equations developed by Johnsen \& Scholz (1989) for adolescent girls in a north-European country were adopted to predict BF\%, as follows:

(a) female 11-13 years

$$
\begin{aligned}
\mathrm{BF} \%=-7.39 & +6.91 \times \ln \mathrm{SFT} \text { (triceps) } \\
& +5.35 \times \ln \text { SFT (subscapular) } \\
& +0.74 \times \ln \text { SFT (suprailiac) }
\end{aligned}
$$

(b) female 15-17 years

$$
\begin{aligned}
\mathrm{BF} \%=-11.82 & +4.39 \times \ln \text { SFT (triceps) } \\
& +4.69 \times \ln \text { SFT (subscapular) } \\
& +4.14 \times \ln \text { SFT (suprailiac). }
\end{aligned}
$$

(c) The weight of body fat (BF; $\mathrm{kg}$ ) was estimated by means of the equation:

$$
\mathrm{BF}(\mathrm{kg})=\frac{\text { body fat }(\%) \times \text { actual body weight }(\mathrm{kg})}{100} .
$$

(d) Lean body mass ( $\mathrm{LBM} ; \mathrm{kg}$ ) was assumed to be the actual body weight $(\mathrm{kg})$ minus BF $(\mathrm{kg})$. The optimum weight (OPW; $\mathrm{kg}$ ) table for age and height of adolescences derived from Ketz (1990) was used and where a value could not be found in the table, the value was derived from the quoted data of Baldwin (1925) as reproduced by Jellife (1966).

(e) Relative weight (RW\%) was calculated from the equation:

$$
\mathrm{RW} \%=\frac{\text { actual body weight }(\mathrm{kg}) \times 100}{\text { optimum weight }(\mathrm{kg})} .
$$

\section{Measurement of energy cost of specific activities}

The volume of expired air $\left(\mathrm{V}_{\mathrm{E}}\right)$ was measured using a respirometer (Model 59/72 of MaxPlanck Institute for Work, Physiology, Dortmund, Germany). The respirometer was linked to a Hans Rudolph face mask, model N7900 series (Kansas City, USA) which was available in three sizes, large, medium and small. The energy costs of two activities, sitting ( $n$ 15) and walking $(n 10)$, were measured using IC. The methods used for collection of expired air and analysis of the air for $\mathrm{O}_{2}$ and $\mathrm{CO}_{2}$ concentrations have been reported previously (Cole \& Ogbe, 1987; Cole \& Ogungbe, 1987; Cole et al. 1989).

\section{$B M R$}

The BMR values were calculated using the FAO/WHO/UNU (1985) equations for the prediction of BMR for adolescents and adults. 


\section{Statistical analysis}

Values are given as means and standard deviations. The Pearson correlation coefficient was employed to assess the relationship between the predicted BC from SFT and EI. The 0.05 level of probability was used to assess statistical significance.

\section{RESULTS}

\section{Anthropometry}

The physical characteristics of the twenty-two adolescent girls are displayed in Table 1. The mean BMI was $19.5 \mathrm{~kg} / \mathrm{m}^{2}$ with a range of between 16.5 and $23.3 \mathrm{~kg} / \mathrm{m}^{2}$. Correlation coefficients between BMI and other anthropometric variables were significant (Table 2). BMI correlated more strongly with BF $(\mathrm{kg})(r 0.83 ; P<0.05)$ and $\mathrm{LBM}(\mathrm{kg})(r$ 0.72; $P<0.05)$, than with BF\% ( $r 0.59 ; P<0.05)$. There was a strong correlation between BMI and body weight $(r 0.84 ; P<0.05)$ but a weaker correlation with height $(r 0.36 ; P<0.05)$. There was also a significant correlation between BMI and RW\% $(r 0.69 ; P<0.05)$.

\section{Skinfold thickness}

SFT values for the group were variable (Table 1), indicating different extents of subcutaneous fat deposition and different distribution patterns. Triceps SFT correlated strongly with BF\% $(r 0.80 ; P<0.05)$ and BF $(\mathrm{kg})(r 0.79 ; P<0.05)$. Subscapular SFT correlated more strongly with BF\% $(r 0.82 ; P<0.05)$ than BF $(\mathrm{kg})(r 0.72 ; P<0.05)$ while suprailiac SFT correlated highly with BF\% $(r 0.71 ; P<0.05)$ and even more strongly with $\mathrm{BF}(\mathrm{kg})(r 0.78 ; P<0.05)$.

Table 1. Physical characteristics, anthropometry and body composition of Nigerian adolescent girls

(Mean values and standard deviations for twenty-two girls)

\begin{tabular}{|c|c|c|}
\hline Characteristics & Mean & SD \\
\hline Age (years) & 13.6 & 1.9 \\
\hline Body wt (kg) & 49.1 & 7.9 \\
\hline Height (m) & 1.58 & 0.10 \\
\hline BMI $\left(\mathrm{kg} / \mathrm{m}^{2}\right)$ & 19.5 & $2 \cdot 0$ \\
\hline $\operatorname{BMR}(\mathbf{k J} / \mathrm{d})$ & 5627 & 401 \\
\hline$(\mathrm{kcal} / \mathrm{d})$ & 1346 & 96 \\
\hline \multicolumn{3}{|l|}{ Anthropometry } \\
\hline \multicolumn{3}{|l|}{ Skinfold thickness (mm) } \\
\hline Triceps & 12.5 & $4 \cdot 1$ \\
\hline Subscapular & 9.3 & 2.7 \\
\hline Suprailiac & 10.4 & $4 \cdot 1$ \\
\hline \multicolumn{3}{|l|}{ Body composition } \\
\hline Body fat (\%) & 21.7 & 3.8 \\
\hline Body fat (kg) & 10.8 & $3 \cdot 1$ \\
\hline Lean body mass $(\mathrm{kg})$ & $38 \cdot 3$ & 5.6 \\
\hline Optimum weight (kg) & 47.6 & 7.3 \\
\hline Relative weight (\%) & 104.0 & $10 \cdot 6$ \\
\hline
\end{tabular}


Table 2. Correlation coefficients between physical characteristics and body composition variables for a group of twenty-two Nigerian adolescent girls in Ibadan, Nigeria

\begin{tabular}{|c|c|c|c|c|c|c|c|c|c|}
\hline & $\begin{array}{c}\text { Age } \\
\text { (years) }\end{array}$ & $\begin{array}{c}\text { Body wt } \\
\text { (kg) }\end{array}$ & $\begin{array}{l}\text { Height } \\
\text { (m) }\end{array}$ & $\begin{array}{c}\text { BMI } \\
\left(\mathrm{kg} / \mathrm{m}^{2}\right)\end{array}$ & $\begin{array}{l}\text { Body fat } \\
(\%)\end{array}$ & $\begin{array}{c}\text { Body fat } \\
\text { (kg) }\end{array}$ & $\begin{array}{c}\text { LBM } \\
(\mathrm{kg})\end{array}$ & $\begin{array}{l}\text { OW } \\
(\mathrm{kg})\end{array}$ & $\begin{array}{l}\text { RW } \\
(\%)\end{array}$ \\
\hline \multicolumn{10}{|l|}{ Age (years) } \\
\hline Body wt (kg) & 0.13 & & & & & & & & \\
\hline Height (m) & 0.39 & 0.80 & & & & & & & \\
\hline BMI $\left(\mathrm{kg} / \mathrm{m}^{2}\right)$ & 0.13 & 0.84 & $0 \cdot 36$ & & & & & & \\
\hline Body fat (\%) & -0.42 & 0.45 & 0.13 & 0.59 & & & & & \\
\hline Body fat (kg) & 0.21 & 0.82 & 0.51 & 0.83 & 0.88 & & & & \\
\hline LBM $(\mathrm{kg})$ & 0.29 & 0.95 & 0.84 & 0.73 & 0.15 & 0.60 & & & \\
\hline $\mathrm{OW}(\mathrm{kg})$ & 0.29 & 0.45 & 0.64 & 0.52 & 0.45 & 0.82 & 0.82 & & \\
\hline RW (\%) & 0.25 & 0.45 & 0.07 & 0.69 & 0.64 & 0.60 & 0.30 & 0.24 & \\
\hline
\end{tabular}

LBM, lean body mass; OW, optimum weight; RW, relative weight.

\section{Body composition}

BC values are presented in Table $1 . \mathrm{BF} \%$ in the girls ranged between 15.1 and $31.1 \%$, while the analogous LBM range was $26.8-46.7 \mathrm{~kg}$. The results indicate that tall individuals in the group possessed greater LBM than short subjects.

\section{$B M R$}

The mean BMR was $5627 \mathrm{~kJ}(1346 \mathrm{kcal}) / \mathrm{d}$ for the group of adolescent girls, and the EI : BMR ratio was $1 \cdot 2$. Nine subjects $(41 \%)$ recorded EI values which were less than 1.2 times BMR. It was also observed that none of these nine girls was either short for her age or underweight.

The correlation coefficients of BMR and other variables were evaluated. BMR values $(\mathrm{kJ} / \mathrm{d})$ correlated highly with body weight $(r 1.00 ; P<0.05)$ and LBM $(r 0.95 ; P<0.05)$ but less strongly with BF\% $(r 0.45 ; P<0.05)$. There was no significant correlation between BMR and EI $(r 0.13 ; P<0.05)$ or between age and BMR $(r 0.13 ; P<0.05)$.

\section{Energy intake}

Table 3 shows the mean EI and the percentages of energy obtained from protein, fat and carbohydrate. Substantial variations were observed in EI during the five consecutive days

Table 3. Mean daily energy intake and percentage contribution of carbohydrate (CHO), fat and protein to the total energy intake during the study period in twenty-two Nigerian

adolescent girls

(Mean values, standard deviations and ranges)

\begin{tabular}{lcccccc}
\hline \hline & & & & \multicolumn{3}{c}{ Distribution (\% energy) } \\
\cline { 5 - 7 } & $\begin{array}{c}\text { Body wt } \\
(\mathrm{kg})\end{array}$ & $\begin{array}{c}\text { Energy intake } \\
(\mathrm{kJ} / \mathrm{d})\end{array}$ & $\begin{array}{c}\text { Energy intake } \\
(\mathrm{kJ} / \mathrm{kg} \text { body wt) }\end{array}$ & CHO & Fat & Protein \\
\hline Mean & 49.1 & 6510 & 132.6 & $59 \cdot 2$ & 28.3 & 12.5 \\
SD & 7.9 & 855 & 27.8 & 1.4 & 1.5 & 0.5 \\
Range & $34.0-61.0$ & $5134-8326$ & $86.2-189.8$ & $57.7-62.1$ & $25.0-31.2$ & $11.6-13.4$ \\
\hline \hline
\end{tabular}


Table 4. Contribution of breakfast, lunch and supper to total energy intake during the study period on the twenty-two Nigerian adolescent girls

(Mean values, standard deviations and ranges)

\begin{tabular}{|c|c|c|c|}
\hline & \multicolumn{3}{|c|}{ Distribution (\%) } \\
\hline & Breakfast & Lunch & Supper \\
\hline Mean & 21.5 & 41.0 & 37.4 \\
\hline SD & 7.5 & 7.8 & 5.5 \\
\hline Range & $7.8-83.0$ & $24 \cdot 4-54.9$ & $29 \cdot 3-46.9$ \\
\hline
\end{tabular}

Table 5. Metabolic variables used in the determination of the energy costs of sitting and walking in Nigerian adolescent girls

(Mean values and standard deviations)

\begin{tabular}{|c|c|c|c|c|c|c|}
\hline & \multirow{2}{*}{$\begin{array}{c}\mathrm{V}_{\mathrm{E}}(\mathrm{STPD}) \\
\text { (litres/min) }\end{array}$} & \multirow{2}{*}{$\begin{array}{c}\dot{\mathrm{V}}_{\mathrm{CO} 2} \\
\text { (litres/min) }\end{array}$} & \multirow{2}{*}{$\begin{array}{c}\dot{\mathrm{V}}_{\mathrm{O} 2} \\
\text { (litres/min) }\end{array}$} & \multirow[b]{2}{*}{$\mathbf{R Q}$} & \multicolumn{2}{|c|}{ Energy cost } \\
\hline & & & & & $(\mathrm{kJ} / \mathrm{min})$ & (kcal/min) \\
\hline \multicolumn{7}{|c|}{ Sitting (n 15) } \\
\hline Mean & 7.333 & 0.167 & 0.225 & 0.74 & 5.0 & $1 \cdot 2$ \\
\hline SD & 2.417 & 0.051 & 0.069 & 0.05 & $1 \cdot 3$ & $0 \cdot 3$ \\
\hline \multicolumn{7}{|c|}{ Walking ( $n$ 10) } \\
\hline Mean & 12.283 & 0.374 & 0.451 & 0.72 & $9 \cdot 1$ & $2 \cdot 2$ \\
\hline SD & 3.475 & 0.088 & 0.131 & 0.04 & 2.8 & 0.7 \\
\hline
\end{tabular}

$\mathrm{V}_{\mathrm{E}}$ (STPD), expired ventilation corrected to standard temperature $\left(0^{\circ}\right)$ and pressure, $(760 \mathrm{mmHg})$ dry; $\dot{\mathrm{V}}_{\mathrm{CO}_{2}}, \mathrm{carbon}$ dioxide production; $\dot{\mathrm{V}}_{\mathrm{O}_{2}}$, oxygen consumption; $R Q$, respiratory quotient.

of the study. The average EI was about $133 \mathrm{~kJ}(32 \mathrm{kcal}) / \mathrm{d}$ per $\mathrm{kg}$ body weight. Mean BMR was $5632 \mathrm{~kJ}(1346 \mathrm{kcal}) / \mathrm{d}$. The EI ranged between $8326 \mathrm{~kJ}(1990 \mathrm{kcal}) / \mathrm{d}$ and $5134 \mathrm{~kJ}$ $(1227 \mathrm{kcal}) / \mathrm{d}$, while the analogous BMR range was $6234 \mathrm{~kJ}(1490 \mathrm{kcal}) / \mathrm{d}$ to $4858 \mathrm{~kJ}$ (1161 kcal)/d. The contributions made by breakfast, lunch and supper to total energy intake are given in Table 4.

\section{Energy cost of specific activities}

Table 5 shows mean values for variables measured during indirect calorimetry, and the energy costs of sitting and walking derived from these. The mean energy cost of sitting ( $n$ 15) was 5.0 (SD 1.3) kJ/min or 0.102 (SD 0.026) $\mathrm{kJ} / \mathrm{kg}$ body weight per min. During walking $(n 10)$ this increased to $9 \cdot 1$ (SD $2 \cdot 8) \mathrm{kJ} / \mathrm{min}$.

\section{DISCUSSION}

\section{Energy and nutrient intakes}

This study is the first of its kind for a group of Nigerian female adolescents in a boarding hostel in Nigeria. Interpretation of the results is complicated by the fact that no reference standards for Nigerian subjects are available. However, in comparison with values reported 
in similar studies in Borno State, Nigeria (Oguntona et al. 1987), USA (Garn et al. 1985; Pao et al. 1985), UK (Hackett et al. 1983) Australia (McNaughton \& Audrey, 1970; Woodward et al. 1981), New Zealand (Tan et al. 1989) and Northern Ireland (Barker et al. 1989) the EI values observed in the present study were low.

The FAO/WHO/UNU (1985) recommendations specify that adolescent girls aged 1117 years require, on average, $8318 \mathrm{~kJ}(1988 \mathrm{kcal}) / \mathrm{d}$. This is significantly higher than the EI observed for adolescent girls in the present study, which was $6510 \mathrm{~kJ}(1556 \mathrm{kcal}) / \mathrm{d}$. However, this does not necessarily indicate that our subjects were energy-deficient, since the girls' level of activity may not have warranted a higher EI. Durnin (1990) measured the EI of a group of adult Indian women living in rural areas who did no physical activity at leisure time, and found it to be $7113 \mathrm{~kJ}(1700 \mathrm{kcal}) / \mathrm{d}$, which is not significantly different from the present value. Similarly, Bleiberg et al. (1981) estimated intakes of $8987 \mathrm{~kJ}$ $(2148 \mathrm{kcal}) / \mathrm{d}$ for males and $6339 \mathrm{~kJ}$ (1515 kcal)/d for female farmers in Upper Volta (now Burkina Faso). It is interesting to note that the EI of the female Burkinabe farmers was lower than that of our subjects. Lower or similar EI values have also been found for pregnant women in The Gambia (Prentice et al. 1981) and rural Kenya (Jansen et al. 1984) and non-pregnant, non-lactating women living in rural East Java (Kardjati et al. 1983).

It is possible that our subjects may have deliberately consumed less than their normal EI during the period of the study. However, personal contact with the girls suggested that no difference in behaviour occurred as a result of participating in the study. Alternatively the food supplied by the school canteen may not have been adequate. It is not possible to ascertain whether the measured EI reported in the present study approximated the normal EI of the girls in their own homes.

The assessment of specific nutrient intakes and individual meals showed that carbohydrate, protein and fat contributed $59.2,12.5$ and $28.3 \%$ of energy respectively, while breakfast, lunch and supper shares were $21.5,41.0$ and $37.4 \%$ respectively. In a previous study of rural and urban adolescent females in Bornu State in the northern part of Nigeria (Oguntona et al. 1987), subjects obtained higher proportions of energy from protein and carbohydrate and a lower proportion of energy from fat than girls in the present study. The discrepancy is probably explained by the different dietary habits of Nigerians in the north and south of the country. In the north, millet, maize, rice, sorghum and meat or fish predominate in the diet, with only small amounts of fat and oil being consumed. In the south-west foods such as cassava (Manihot esculenta), yam (Dioscorea esculenta), meat, fish, fat and oil are common. The differences may explain the variation in energy contribution of carbohydrate, protein and fat to the total EI of the two groups of Nigerians.

The low energy intakes observed in the present study might be explained by the low energy density of the diet. In comparison with the diets typical of Europe, America and some other African countries (e.g. Ghana), the Nigerian diet contains little fat. In the present study, carbohydrate contributed $59.2 \%$ of total energy (Table 3). Consumption of butter and milk was minimal; fat was provided largely by palm and groundnut oils which were used for frying plantains (dodo) or eggs, and in preparing stews. Protein was obtained largely from imported frozen fish (mostly mackerel), beef, pulses such as beans (Vignia spp.) and egg. Protein foods are expensive in Ibadan, and this may have been the reason for the relatively low protein intake.

Fresh green vegetables and fruits are traditionally considered to be ruminant feed and do not form part of the staple diet for many Nigerians, except the upper class. Availability and seasonality may also have precluded these foods from the diet in the present study. 


\section{$B M R$}

The mean BMR of the girls in the present study was $5632 \mathrm{~kJ}(1346 \mathrm{kcal}) / \mathrm{d}$, which is very similar to the average value for adolescent girls aged 11-17 years predicted from $\mathrm{FAO} / \mathrm{WHO} / \mathrm{UNU}(1985)$ equations $(5590 \mathrm{~kJ}(1336 \mathrm{kcal}) / \mathrm{d})$. Analysis of variables showed that only BMI and LBM were significantly correlated with the predicted BMR ( $r 0.84$ and 0.95 respectively, $P<0.05)$. BMR $(\mathrm{kJ} / \mathrm{d})$ did not display any correlation with daily $E I$.

It is not clear whether the equations of Schofield (1985) and FAO/WHO/UNU (1985) for predicting BMR are suitable for use with African populations. The FAO/WHO/UNU (1985) equations are thought to be derived from western European subjects; those of Schofield (1985) included some data from Asian and Latin American countries and have recently been used as the basis of new international predictive equations for estimating energy requirements. However, the lack of locally derived equations may represent a problem for African nutritionists. The BMR values obtained in the present study were based on equations derived from subjects who probably had a higher percentage of body fat than our girls, and therefore may not be accurate. There have been numerous, often conflicting, reports of differences in BMR values between different racial groups (Henry et al. 1988), and of differences in proportions of LBM among individuals with different energy and nutrient intakes (Cole et al. 1989). Another factor which affects BMR is climate (Mason \& Jacob, 1992). It has been observed that BMR for tropical populations is substantially below that predicted from regression equations derived from data obtained from Western subjects (Scott-McGregor \& Loh, 1940; Bannerjee \& Sen, 1958; Schofield, 1985). For these reasons, the application of regression equations derived from one population to another population may lead to erroneous results. For example, Bingham (1987) has suggested that if the habitual EI of an individual is found to be less that 1.4 times BMR it is almost certainly an underestimation and that such results indicate either under-reporting of food intake, or a reduction of EI during the experimental period. Other researchers have also suggested that intakes which are less than 1.2 times BMR should be excluded from results because they cannot be representative of habitual intake. In the present study, nine of our adolescent girls had an average EI less than 1.2 times BMR; however, we consider it highly unlikely that the food intakes of the girls were not typical of their habitual diet.

\section{Energy cost of specific activities}

The habitual physical activity of children and adolescents differs among societies with different cultural characteristics and among groups of different socioeconomic conditions in the same society, so also ECSA will differ. For example, while many children in rural areas and some in the cities of Nigeria perform domestic chores or are part of the labour force of the country from childhood, most children and adolescents in industrialized countries attend school or serve as apprentices for several hours each day. The lucky ones from higher socioeconomic groups do not have any such work obligations. However, the total amount of energy used each minute is greater in larger than in smaller people: the energy needed to move about will also be greater in larger individuals.

Very few studies of ECSA in children and adolescents using indirect calorimetry $\left(\mathrm{O}_{2}\right.$ consumption and $\mathrm{CO}_{2}$ production) have been conducted in Nigeria. The values obtained from the present study show mean values of $5.0 \mathrm{~kJ}(1.2 \mathrm{kcal}) / \mathrm{min}$ for sitting and $9.1 \mathrm{~kJ}$ $(2.2 \mathrm{kcal}) / \mathrm{min}$ for walking activities respectively (Table 5).

The results from the present study are similar to those from other parts of the world (Torun, 1989). However, the problem of classification of the various activities into main 
activities has now emerged. In the West about five categories of activities are commonly used (sleep, sedentary, light, moderate, and heavy activities). Some researchers have also included 'very heavy'. These five or six categories of activities may not be appropriate for use in Nigeria at this stage of our technological development. Therefore, it is necessary for Nigerian and West African nutritionists and work physiologists to consider how best to classify their own activities relevant to our development standing.

\section{Anthropometry}

Skinfold thickness. The SFT values for girls in the present study were comparable with previous findings in terms of fat patterning and distribution (Cronk \& Roche, 1982). There was a tendency for subcutaneous fat to be deposited preferentially in suprailiac and subscapular areas. The triceps SFT values were similar to those of British children (Tanner \& Whitehouse, 1962), French-Canadian school-age children (Jenicek \& Demirjian, 1972) and American female university students (Wilmore \& Behnke, 1970).

The relative SFT values at various sites have been reported to vary in accordance with the fatness of individuals (Edwards, 1951; Garn, 1955; Newman, 1955). Similarly, in longitudinal studies, some sites may change with time more than others and indeed, some sites may increase while others may decrease (Garn \& Young, 1956). With maturity, fat distribution tends to shift from the extremities to the trunk (Muller, 1982). These changes begin to occur in adolescence. Garn et al. (1985) observed that during childhood and adolescence, fatter individuals were also taller, had more LBM and exhibited developmental advancements, including early maturity. In the present study we observed, also, that fatter girls (TBF\%) were taller than those with less body fat. However, our results do not allow us to comment on developmental advancement.

Relative body weight. In the present study, 'relative body weight' means the actual body weight expressed as a percentage of the individual optimum weight $(\mathrm{kg})$. Optimum weight is a statistical quantity which correlates with highest life expectancy in a large group of people. People whose weight falls within the range of $\pm 10 \%$ of optimum weight are regarded as normal weight (Mohr, 1969, 1982). The usefulness of this comparison depends on the appropriateness of the reference standard used to determine optimum weight. For this purpose some developing countries adopt the international or specific country's reference standards while others utilize standard data for comparative purposes. It is not clear how applicable such reference standards are for different populations. Average values for weight and height for a particular age and sex for a specific population do not necessarily correspond to those of other populations or even to the same population at another time.

In the present study, using optimum weight values from Ketz (1990), 68.2\% of the girls were underweight, $18.2 \%$ were within the normal weight range and $13.6 \%$ could be classified as overweight. If optimum weight standards derived from a local Nigerian population had been used, these results may have been markedly different.

\section{Body composition}

For prediction of percentage body fat in the present study it was necessary to adopt population-specific equations developed in northern European adolescent girls because no Nigerian equations are available. Using the European equations it was possible to obtain values of TBF\% for Nigerian adolescent girls for the first time. The mean value was very low compared with that for the analogous age group for which the original equation was 
derived. This is not surprising in view of the lower energy and nutrient intakes of Nigerian girls compared with Europeans. The values were, however, higher than those obtained for female nursing students (aged 20-25 years) from University College Hospital, Ibadan and Iyienu Hospital, Enugu, Nigeria (Cole \& Udekwe, 1989).

\section{CONCLUSION}

In conclusion, the present paper provides useful information on energy intakes, body composition and metabolic rates of adolescent girls in Nigeria, together with qualitative data on the types of foods eaten. It is not clear whether the observations are specific to the period of investigation or whether they are typical of the whole year. Further studies are needed to confirm these findings.

The authors are grateful for partial support from Senate Grants Funds of the University of Ibadan. The authors are appreciative of the assistance of the Nestle Nutrition Research Grant Programme Committee, London under the chairmanship of Professor J. C. Waterlow, CMG, FRCP, FRS, who provided the grant for the acquisition of the major equipment in the First Human Energy Metabolism Laboratory in Nigeria where all our research studies were conducted. We acknowledge with thanks the participation of the adolescent girls of the 1988-1989 session of the International School, University of Ibadan in these studies. We also wish to thank Dr Susan Kingman for expert assistance with the writing of this paper.

\section{REFERENCES}

Association of Official Analytical Chemists (1980). Official Methods of Analysis, 13th ed. Washington, DC: AOAC.

Bannerjee, S. \& Sen, R. (1958). Body composition of Indians and its relation to basal metabolic rate. Journal of Applied Physiology 12, 29-33.

Barasi, M. E. \& Mottram, R. F. (1992). Nutrition in special age groups. In Human Nutrition pp. 142-164. London, Melbourne: Edward Arnold.

Barker, M. E., Thompson, K. A., Evason, E. M. T. \& Woods, R. (1989). The nutritional intake of school children in Northern Ireland - a comparison of two school-meal systems. Proceedings of the Nutrition Society 48, 74A.

Bingham, S. A. (1987). The dietary assessment of individuals, methods, accuracy, new techniques and recommendations. Nutrition Abstracts and Reviews 57, 705-742.

Bleiberg, F. M., Brun, T. A., Goimans, S. \& Liffman, D. (1981). Food intake and energy expenditure of male and female farmers from Upper-Volta. British Journal of Nutrition 45, 505-515.

Cole, A. H., Ibeziako, P. A. \& Bamgboye, E. A. (1989). Basal metabolic rate and energy expenditure of pregnant Nigerian women. British Journal of Nutrition 62, 631-637.

Cole, A. H. \& Ogbe, J. O. (1987). Energy intake, expenditure and pattem of daily activity of Nigerian male students. British Journal of Nutrition 58, 357-367.

Cole, A. H. \& Ogungbe, R. F. (1987). Food intake and energy expenditure of Nigerian female students. British Journal of Nutrition 57, 309-318.

Cole, A. H. \& Udekwe, I. O. (1989). Body composition, energy, protein and iron intake of Nigerian female nursing students. Die Nahrung 33, 703-708.

Cronk, C. E. \& Roche, A. F. (1982). Race- and sex-specific reference data for triceps and subscapular skinfolds and weight/stature. American Journal of Clinical Nutrition 35, 347-354.

Durnin, J. V. G. A. (1990). Low energy expenditure in free-living populations. European Journal of Clinical Nutrition 44, Suppl. 1, 95-102.

Durnin, J. V. G. A., Blake, E. C. \& Brockway, J. M. (1957). The energy expenditure and food intake of middle aged Glasgow housewives and their adult daughters. British Journal of Nutrition 11, 85-98.

Edwards, D. W. (1951). Differences in the distribution of subcutaneous fat with sex and maturity. Clinical Science 10, 305-315.

Food and Agriculture Organization/World Health Organization (1973). Energy and Protein Requirements. Technical Report Series. no. 522. Geneva: World Health Organization. 
Food and Agriculture Organization/World Health Organization/United Nations University (1985). Energy and Protein Requirements. Technical Report Series no. 724. Geneva: World Health Organization.

Garn, S. M. (1955). Relative fat patterning on individual characteristics. Human Biology 27, 75-89.

Garn, S. M., Ryan, A. S. \& Higgin, M. W. (1985). Implication of fatness and leaness. American Journal of Physical Anthropometry 57, 191 Abstr.

Garn, S. M. \& Young, R. W. (1956). Concurrent fat loss and fat gain. American Journal of Physical Anthropometry 14, 497-504.

Garty, R. C., Passmore, R., Warnock, G. M. \& Durnin, J. V. G. A. (1959). Studies on Expenditure of Energy and Consumption of Food by Miners and Clerks. Medical Research Council Special Report Series no. 289. London: MRC.

Hackett, A. F., Rugg-Gunn, A. J. \& Appleton, D. R. (1983). The use of dietary diary and interview to estimate the food intake of children. Human Nutrition: Applied Nutrition 37A, 293-300.

Haenel, H. (1979). Energie and Nahrstoffgehalt von Lebensmitteln: Lebenmitteltabellen (Energy and Nutrient Content of Foodstuffs: Food Composition Table). Berlin: Vokseigner Betrieb Verlag Volks and Gesundheit.

Henry, C. J. K., Piggot, S. \& Emery, B. (1988). Basal metabolic rate and diet-induced thermogenesis in Asians living in Britain. Human Nutrition: Clinical Nutrition 41C, 397-402.

Jansen, A. A. J., Kusin, J. A., Thiur, B., Lakhan, S. A. \& Mannetje, W. (1984). Anthropometric changes during pregnancy in rural African women. Tropical and Geographical Medicine 36, 91-97.

Jelliffe, D. B. (1966). The Assessment of the Nutritional Status of the Community. Geneva: WHO.

Jenicek, M. \& Demirjian, A. (1972). Triceps and subscapular skinfold thickness in French-Canadian school-age children in Montreal. American Journal of Clinical Nutrition 25, 576-581.

Johnsen, D. \& Scholz, C. (1989), Anthropometrische Methoden zur Ermittlung und Beuteilung des Emahrungszustandes des Menschen (Anthropometric methods for the assessment and estimation of nutritional status of man). Wissennchaftliche: Zeitschrift der Humboldt Universitat zur Berlin. R. Medizin 38, 218-226.

Kardjati, S., Kusin, J. A. \& De With, C. (1983). Food consumption of nural women in East Java, Indonesia. Nutrition Reports International 28, 1341-1349.

Ketz, H.-A. (1990). Bestimmung des Emahrungszustandes (Assessment of nutritional status). In Grundriss der Ernahrungslehre, 3rd ed., pp. 388-401. Jena: VEB Gustav Fisher Verlag.

McNaughton, J. W. \& Audrey, J. C. (1970). A study of food intake and activity of a group of urban adolescents. British Journal of Nutrition 24, 331-344.

Marr, J. W. (1971). Individual dietary survey. Purposes and methods. World Review of Nutrition and Dietetics 13, 105-164.

Mason, E. D. \& Jacob, M. (1992). Variations in basal metabolic rate responses to changes between tropical and temperate climates. Human Biology 44, 141-172.

Mohr, M. (1982). On the definition of obesity. 2nd Anthropological Congress of Ales Hrdlick-Universitas Carolina Pragensis, 189-192.

Mohr, M. (1969). Vereinfachte Korrekturen zur individuaallen Optimalgewichs-bestimmung Humanbiologic (Simplified corrections of the individual determination of optimum weight). Das Deutsche Gesundheitswesen 24, 1667.

Muller, W. H. (1982). The changes with age of the anatomical distribution of fat. Social Science and Medicine 16, 191.

Newman, R. W. (1955). Skinfold changes with increasing obesity in young American males. Human Biology 27, $53-64$.

Oguntona, C. R. B., Oguntona, T. E., Williams, L. S. \& Biu, K. A. (1987). The food and nutrient intake of adolescents in Borno, Nigeria. Nutrition Reports International 36, 981-987.

Pao, F. M., Mickle, S. J. \& Burk, M. C. (1985). One-day and 3-day nutrient intake by individuals: nationwide food composition survey findings, Spring 1977. Joumal of the American Dietetic Association 85, 313-324.

Prentice, A. M., Whitehead, R. G., Roberts, S. B. \& Paul, A. A. (1981). Long-term energy balance in childbearing Gambian women. American Journal of Clinical Nutrition 34, 2790-2799.

Schofield, W. N. (1985). Predicting basal metabolic rate: new standards and review of previous work. Human Nutrition: Clinical Nutrition 39, Suppl. 1, 5-41.

Scott-McGregor, R. G. \& Loh, G. L. (1940). The comparison of basal physiological values in racial groups. Journal of the Malay Branch of British Medical Association 4, 217-260.

Southgate, D. A. T. \& Durnin, J. V. G. A. (1970). Calorie conversion factors. An experimental reassessment of the factors used in the calculation of energy value of human diets. British Journal of Nutrition 24, 517-535.

Tan, S. P., Wells, J. E., Beaven, D. W. \& Hornblow, A. R. (1989). Energy and macronutrient intake of New Zealand adolescents. Ecology of Food and Nutrition 23, 225-236.

Tanner, J. M. \& Whitehouse, T. (1962). Standards for subcutaneous fat in British children. British Medical Journal 1, 446-451.

Torun, B. (1989). Energy cost of various physical activities in healthy children. In Activity, Energy Expenditure and Energy Requirements of Infants and Children, pp. 139-182. Proceedings of an IDECG Workshop. Cambridge, Massachusetts. 
Wilmore, J. H. \& Behnke, A. R. (1970). Anthropometric estimation of body density and lean body weight in young women. American Journal of Clinical Nutrition 3, 267-274.

Woodward, D. R., Lynch, P. P., Waters, M. J., Maclean, A. R., Ruddock, W. E., Rataj, J. W. \& Lemoh, J. N. (1981). Dietary studies on Tasmanian high school students. Intakes of energy and nutrients. Australian Paediatrics 17, 196-201. 